Ritrýnd grein birt 31. desember 2018

\title{
Kynlífsvirkni unglinga og samskipti peirra við foreldra
}

\author{
Kolbrún P. Pálsdóttir og Ársæll Arnarsson
}

- Abstract $\backslash$ Um höfundana About the authors $>$ Heimildir

Íslensk ungmenni byrja að stunda kynlíf að jafnaði fyrr en flest önnur evrópsk ungmenni. Unglingar sem byrja snemma að hafa samfarir eru í aukinni hættu á að upplifa neikvæðar afleiðingar kynlífs, svo sem pvingun, smitsjúkdóma og ótímabærar punganir. Miklu skiptir að foreldrar leggi sig fram um að skapa traust til að ungmenni geti leitað til peirra og rætt vangaveltur sínar og áhyggjur. Markmið pessarar rannsóknar er að varpa ljósi á tengsl milli kynlífsvirkni íslenskra unglinga og pess hversu auðvelt peim finnst að tala við foreldrana um áhyggjur sínar. Einnig er skoðað hvort tengsl séu milli kyn foreldris og kyns unglings og ofangreindra pátta. Niðurstöður byggjast á albjóðlegu rannsókninni Heilsa og lífskjör skólabarna (HBSC) sem lögð var fyrir íslenska unglinga í febrúar 2014. Pátttakendur voru 3.618 nemendur úr 10. bekk sem mættir voru í skólann pann dag sem könnunin var lögð fyrir. Niðurstöður sýna að um fjórðungur svarenda hefur haft samfarir, 24,4\% pilta og 23,0\% stúlkna. Dá sýna gögnin að unglingar sem eiga erfitt með að tala við foreldra sína um pað sem veldur peim áhyggjum eru líklegri til pess að hafa byrjað snemma að hafa samfarir en jafnaldrar peirra. Bæði kyn virðast vera í lakari samskiptum við feður sína en mæður og stúlkur meta pau verri en strákar. Mest áhrif á kynlífsvirkni sjást meðal peirra unglinga sem meta samskipti sín við feður mjög erfið, par sem peir sem hafa haft samfarir eru um pað bil tvöfalt líklegri til að meta samskiptin með peim hætti en peir sem aldrei hafa stundað kynlíf. Rannsóknin sýnir að ákveðinn hópur unglinga í 10. bekk sem er byrjaður að stunda kynlíf telur sig eiga erfitt með að ræða við foreldra sína. Niðurstöður gefa tilefni til pess að kannað sé hvernig veita megi peim hópi betri stuðning.

Efnisorð: Kynlífsvirkni, unglingar, samskipti, foreldrar, kynjamunur.

\section{Inngangur}

Unglingsárin einkennast af margs konar nýjum sálfræðilegum og félagslegum áskorunum fyrir einstaklinginn. Veigamikill páttur pessa skeiðs er að pá próa ungmennin kynvitund sína og fara að prófa sig áfram í kynlífi. Kynheilbrigði skiptir pví ekki aðeins máli fyrir líkamlega heilsu ungmenna heldur ekki síður hina sálrænu. Kynheilbrigði unglinga hefur enda verið gert að forgangsatriði í stefnumótun flestra vestrænna ríkja í heilbrigðismálum (Avery og Lazdane, 2008; World Health Organization [WHO], 2016). Fyrri rannsóknir bentu til pess að íslensk ungmenni byrjuðu að jafnaði fyrr að stunda samfarir en erlendir jafnaldrar peirra (Sóley S. Bender, 2016), en á síðustu árum hefur dregið verulega úr pví að íslenskir unglingar byrji svo snemma (Inchley o.fl., 2016). Dví yngri sem unglingar eru pegar peir byrja að stunda kynlíf, peim mun meiri líkur eru á að ýmsir áhættupættir fylgi, svo sem pvingad kynlíf, ótímabærar punganir og kynsjúkdómar (Hansen, 2010). Miklu skiptir að ungmenni átti sig á mikilvægi pess að kynlíf eigi sér stað með sampykki beggja aðila og að pað byggist á trausti og gagnkvæmum trúnaði. Pá er mikilvægt að 
pau hafi aðgang að og kunni að nota viðeigandi getnaðarvarnir (Sóley S. Bender, 2012). Einnig er mikilvægt að hafa í huga að fjölmargir upplifa ofbeldishegðun tengda kynlífi, og á pað ekki síst við um unglinga. Í nýlegri íslenskri rannsókn sögðust tæplega 16\% unglinga í 10. bekk hafa orðið fyrir kynferðislegri áreitni eða ofbeldi (Ársæll Arnarsson, Kristín Heba Gísladóttir og Stefán Hrafn Jónsson, 2016).

Áður en lengra er haldið skal tekið fram að í pessari grein er hugtakið kynlífsvirkni notað yfir раð аð stunda samfarir eða hafa sofið hjá. Rétt er að hafa í huga að kynhegðun hefst vissulega mun fyrr og að undir kynlíf fellur fjöldamargt annað en eiginlegar samfarir. Hins vegar verða ákveðin skil pegar einstaklingur fer að stunda samfarir og pví er hér beint sjónum að pví tímabili.

Vandasamt er að draga ályktanir eða yfirfæra niðurstöður alpjóðlegra rannsókna á reynslu og viðhorfum ungmenna af kynlífi og samskiptum við foreldra á íslenskt samfélag og öfugt, par sem menning og félagslegar aðstæður geta verið mjög ólíkar og mótað rannsóknarniðurstöður. Í alpjóðlegri rannsókn á heilsu og líðan skólabarna (Health and Behaviour of School-Aged Children - HBSC) veturinn 2013-2014 kom í ljós að mikill munur var milli pátttökulanda á hlutfalli 15 ára unglinga sem sögðust hafa haft samfarir. Dannig sögðust 40\% búlgarskra pilta hafa haft samfarir samanborið við 15\% hollenskra pilta. Í sömu rannsókn kom fram að 23\% stúlkna og 24\% drengja í 10. bekk á Íslandi höfðu haft samfarir. Sami breytileiki kom einnig fram í smokkanotkun, 7\% grískra pilta sögðust ekki hafa notað smokk við síðustu samfarir samanborið við $72 \%$ pólskra pilta. Meðal íslenskra unglinga sögðust 35\% stúlkna og $28 \%$ stráka ekki hafa notað smokk við síðustu samfarir (Inchley o.fl., 2016).

Flestar rannsóknir sýna að kynlífsvirkni snemma á unglingsárum sé páttur í víðtækari áhættuhegðun par sem einnig getur komið við sögu vímuefnanotkun og óvarið kynlíf (Poulin og Graham, 2001). Bandarísk langtímarannsókn sýndi að pað að byrja snemma að hafa samfarir gat haft mikil áhrif á sjálfsmynd ungmenna, vellíðan, félagslega stöðu og kynhegðun í framtíðinni (Fergus, Zimmerman og Caldwell, 2007). Einnig sýndu niðurstöður rannsakenda töluverðan mun á áhættuhegðun ungmenna eftir kynpætti. Dó kynlífsvirkni ungmenna sé gjarnan tengd við áhættuhegðun er ljóst að ástundun kynlífs er forsenda pess að proskast sem manneskja og skapa náin tengsl við aðra. Heilborn og Cabral (2010) héldu pví til að mynda fram að fara pyrfti varlega í pað að líta ávallt á barneignir ungmenna sem óæskilegar heldur væri um að ræða félagslegt fyrirbæri sem yrði páttur í lífi sumra einstaklinga og gæti jafnvel verið valdeflandi.

Samskipti við foreldra móta andlega, líkamlega og félagslega pætti í lífi unglingsins. Pannig hafa foreldrarnir einnig mótandi áhrif á kynhegðun unglinga sinna. Sálfræðingurinn og geðlæknirinn John Bowlby (1977) setti fram grundvallarkenningu um eðli heilbrigðra tengsla milli foreldra og barna. Hann lýsti pví einnig hvernig skortur á slíkum tengslum leiddi til sálfræðilegra vandamála. Samkvæmt pessari kenningu hafa foreldratengsl áhrif á proska einstaklingsins yfir allt æviskeiðið og setja mark sitt á öll náin sambönd. Рó að pað sé eðlilegur hluti af proska unglingsáranna að einstaklingurinn leiti eftir meira sjálfstæði og að félagahópurinn fái aukið vægi á kostnað foreldranna, pá gegna hinir síðarnefndu enn lykilhlutverki í að styðja börn sín á pessu aldursskeiði. Auknu sjálfræði unglingsins geta oft fylgt annars konar breytingar á sambandi foreldris og barns, svo sem minni nánd og lauslegri tengsl (Bulanda og Majumdar, 2009). Engu að síður hafa mælingar á stuðningi foreldra sýnt fylgni við ýmsa pætti tengda andlegri vellíðan unglinga (Parker og Benson, 2004). Langtímarannsókn Bulanda og Majumdar (2009) leiddi til að mynda í ljós tengsl á milli samskipta við foreldra og sjálfstrausts unglinga. Góð foreldratengsl auka einnig tilfinningalega vellíðan unglinga (Carlson, Sampson og Sroufe, 2003), félagshæfni (Bohlin, Hagekull og Rydell, 2000) og námsárangur (Jacobsen og Hofmann, 1997). Rannsókn Flouri og Buchanan (2003) sýndi enn fremur fram á fylgni milli góðra foreldratengsla og minni tíðni sjálfsvígshegðunar. Slök foreldratengsl hafa á hinn bóginn fylgni við kvíðaraskanir (Warren, Houston, Egeland og Sroufe, 1997), ýgi (Finzi, Ram, Har-Even, Shnit og Weizman, 2001), brottfall úr námi (Marcus og Sanders-Reio, 2001), punglyndi (Graham og Easterbrooks, 2000) og sjálfsvíg (Adams, Sheldon-Keller og West, 1996). 
Niðurstöður rannsókna hafa einnig bent til pess að foreldratengsl hafi bein áhrif á kynhegðun unglinga. Lenciauskiene og Zaborskis (2008) sýndu fram á að unglingar sem áttu í góðum samskiptum við móður sína voru ólíklegri til að hafa byrjað að stunda kynlíf fyrir 16 ára aldur. Fleiri rannsóknir benda til pess að foreldrar, ekki síst mæður, hafi á margvíslegan hátt áhrif á kynlífsvirkni og kynhegðun ungmenna (Commendador, 2010; Wetherill, Neal og Fromme, 2010). Skortur á stuðningi og eftirliti foreldra með ungmenni virðist leiða til minni samskipta og auka líkur á áhættuhegðun og kynlífsvirkni ungmennisins (Wetherill o.fl., 2010). Dó er rétt að hafa 1 huga að ekki er endilega verið að tala um að foreldrar ræði títt og opinskátt um kynlíf við ungmenni sín, heldur fremur að foreldrar séu til staðar og að á milli peirra og barna peirra ríki traust. Til að mynda drógu Lenciauskiene og Zaborskis (2008) pá ályktun af rannsókn sinni að pað að búa við heilsteypt og öruggt fjölskyldumynstur væri mikilvægara en að foreldrar ræddu við börn sín um kynlíf.

Jákvæðu fréttirnar eru pær að ungmenni á Íslandi virðast eyða meiri tíma með foreldrum sínum en áður. Til að mynda sögðust 33\% 14-15 ára unglinga árið 2006 oft eða nær alltaf eyða tíma með foreldrum sínum um helgar en 63\% svöruðu á pennan hátt árið 2014 (Velferðarráðuneytið og Hagstofa Íslands, 2015). Langtímarannsókn í Tékklandi á samskiptum unglinga og foreldra yfir árin 2002-2014 bendir til pess að almennt séu samskipti peirra að styrkjast (Vašíčková, Hodačová, Půžová og Tabaka, 2017). Ný langtímarannsókn á Norðurlöndum (Arnarsson, Portebny, Torsheim og Eriksson, í prentun) sýnir svipaðar niðurstöður. Sérstaklega virðast tengsl norrænna unglinga við feður sína hafa styrkst á undanförnum áratug, en pess ber pó að geta að tengsl peirra við mæður sínar eru samt talsvert sterkari alls staðar á Norðurlöndum. Í rannsókn á samskiptum unglinga við foreldra og sjálfsmynd peirra kom í ljós að stúlkur höfðu tilhneigingu til að vera í nánari samskiptum við foreldra og upplifðu sig undir strangara félagslegu eftirliti. Dó höfðu náin tengsl við foreldra minni áhrif á jákvæða sjálfsmynd stúlkna; drengir sem mátu samskipti við foreldra sterk höfðu yfirleitt jákvæðari sjálfsmynd (Vašíčková o.fl., 2017).

Ýmsum spurningum er enn ósvarað. Til að mynda hefur kynlífsvirkni ungmenna og tengsl við samskipti við foreldra ekki verið könnuð sérstaklega hér á landi. Markmið pessarar rannsóknar er að varpa ljósi á tengsl milli kynlífsvirkni íslenskra unglinga í 10. bekk og pess hversu auðvelt peim finnst að ræða við foreldrana um áhyggjur sínar. Auk pessa vildum við skoða hvort kyn foreldris og kyn unglings hefðu áhrif á svör peirra síðarnefndu.

\section{Aðferð}

Heilsa og lífskjör skólabarna (HBSC) er fjölpjóðleg rannsókn, studd af Alpjóðaheilbrigðismál astofnuninni (WHO), par sem unglingar eru spurðir um ýmsa pætti varðandi heilsu, líðan og félagslegar aðstæður (Inchley o.fl., 2016). Fyrsta fyrirlögnin fór fram veturinn 1983-1984 og hún hefur síðan verið endurtekin fjórða hvert ár. Frá árinu 2006 hefur pessi rannsókn verið lögð fyrir á Íslandi.

Í febrúar 2014 var íslensk pýðing á spurningalista rannsóknarinnar lögð fyrir unglinga í öllum skólum landsins sem mættir voru í skólann fyrirlagnardaginn. Spurningar um kynlífsvirkni voru einungis lagðar fyrir nemendur í 10. bekk, en af peim tóku 3.618 pátt, eða sem samsvarar 85\% allra nemenda á landinu sem pá voru skráđir í 10. bekk. Hér var pví um pýðisrannsókn að ræða með peim fyrirvara að nemendur í sérskólum voru undanskildir. Kynjaskipting var nánast jöfn, $1.783(50,7 \%)$ svarendur voru karlkyns og 1.731 (49,3\%) kvenkyns, en 104 nemendur svöruðu ekki spurningunni um kyn.

Áður en gagnasöfnun hófst var spurningalistinn sendur, ásamt rannsóknaráætlun,til Persónuverndar og Vísindasiðanefndar Háskóla Íslands. Engar athugasemdir voru gerðar við fyrirhugaða framkvæmd. Að pví fengnu voru öllum skólastjórum á Íslandi sem höfðu nemendur í viðkomandi bekkjardeild sendar sömu upplýsingar ásamt ósk um að peir tækju pátt. Aðeins einn skóli hafnaði pátttöku. Síðan var öllum foreldrum og forráðamönnum sent kynningarbréf og peim gefið tækifæri til að hafna pátttöku barnsins. Eitt foreldri kaus að nýta sér pann rétt. 
Notuð var stöðluð aðferð við söfnun gagna í skólunum. Spurningalistum var dreift í ómerktu umslagi meðal nemenda sem mættir voru í kennslustund fyrirlagnardaginn. Borð nemenda voru færð í sundur til pess að tryggja að svarendur sæju ekki svör annarra og hver og einn skilaði svo gögnunum í ómerktu umslagi sem síðan var límt aftur. Á forsíðu listans var stutt lýsing á rannsókninni ásamt skýrum skilaboðum pess efnis að jafnvel pótt foreldrar peirra og skólayfirvöld hefðu gefið leyfi, pá væri nemendum sjálfum algjörlega frjálst að neita pátttöku eða að sleppa pví að svara ákveðnum spurningum. Degar nemendur höfðu lokið við að svara listunum var peim safnað saman og peir settir í lokaðan kassa. Nemendum var pví ljóst að um nafnlausa könnun væri að ræða sem ekki yrði með neinu móti rakin til peirra.

Í pessari grein verður fjallað um niðurstöður spurninga sem vörðuðu kynlífsvirkni unglinga og samskipti peirra við foreldra. Allir pátttakendur í 10. bekk voru beðnir að taka afstöðu til spurningarinnar „Hefur pú einhvern tímann haft samfarir (stundum kallað að sofa hjá)?“ Dessi spurning hefur verið í alpjóðlega HBSC-listanum frá árinu 2001 en er upprunnin úr rannsókninni „Youth Risk Behavior Surveillance“ sem Centers for Disease Control and Prevention framkvæmdi í Bandaríkjunum (Eaton o.fl., 2006). Réttmætisrannsókn sem gerð var í Frakklandi, Írlandi, Rúmeníu og Ungverjalandi (Young, 2013) leiddi í ljós að 96,7\% pátttakenda í HBSC-rannsókninni í pessum löndum tóku afstöðu til pessarar spurningar. Aðeins fjórir af 582 sögðu að erfitt væri að skilja spurninguna og tveir pátttakendur töldu hana of persónulega. Í HBSC-fyrirlögn á Íslandi árið 2006 var í fyrsta sinn spurt sérstaklega um kynhneigð og voru pá notuð helmingaskipti til að skoða áreiðanleika (e. split-half reliability). Í ljós kom að nákvæmlega sama hlutfall svarenda sagðist hafa haft samfarir, óháð pví hvort peir fengu spurningalista með spurningu um aðra kynhneigð eður ei.

Samskipti við foreldra voru metin með pví að spyrja hversu auðvelt unglingarnir ættu með að tala við mæður sínar eða feður um pað sem ylli peim áhyggjum. Svarmöguleikarnir voru fimm: „Mjög auðvelt“, „Auðvelt“, „Erfitt“, „Mjög erfitt“ og „Á ekki við eða hitti ekki viðkomandi“". Dessi spurning hefur verið á HBSC-listanum frá árinu 1994 og nokkrar réttmætisog áreiðanleikarannsóknir verið gerðar en ekki birtar. Í peim hefur Cronbach-alfagildið mælst 0,8. Fylgni við niðurstöður annarra mælitækja hafa verið eftirfarandi: Inventory of parent and peer attachement 0,57 og Multidimensional Scale of Perceived Social Support 0,48. Rýnihóparannsóknir meðal unglinga benda einnig til pess að yfirborðsréttmæti spurningarinnar sé gott.

Gögnin voru skönnuð inn og tölfræðileg úrvinnsla (lýsandi tölfræði og tvíkosta aðhvarfsgreining) var framkvæmd með IBM SPSS-tölfræðiforritinu fyrir Windows (útgáfa 24,0. Armonk, N.Y.: IBM). Fylgibreytan var kynlífsvirkni en frumbreyturnar gæði samskipta, kyn svarenda og kyn foreldra peirra.

\section{Niðurstöður}

Af 3.618 nemendum sem tóku pátt í könnuninni svöruðu 3.545 (98,0\%) spurningunni um pað hvort peir hefðu haft samfarir. Alls sögðust 74,6\% aldrei hafa haft samfarir en $23,4 \%$ svöruðu pví játandi. Piltar voru örlítið líklegri til að svara spurningunni játandi en stúlkur, eða 24,4\% samanborið við $23,0 \%$.

Tafla 1 sýnir tengsl milli kynlífsvirkni unglinga og pess hversu auðvelt peir áttu með að tala við mæður sínar um pað sem ylli peim áhyggjum. Eins og sést af töflunni, pá eru peir unglingar sem hafa haft samfarir tvöfalt líklegri til að eiga í erfiðum samskiptum við mæður sínar en hinir. Pessi áhrif koma sterkar fram hjá stelpum en strákum. Munurinn milli stráka og stelpna kemur helst fram meðal peirra sem segjast eiga mjög auðveld samskipti við móður. Meðal stelpnanna virðist sú upplifun tengjast minni líkum á pví að hafa haft samfarir en munurinn er miklu minni hjá strákunum. 
Tafla 1. Tengsl kynlífsvirkni unglinga í 10. bekk og samskipta við mæður.

\begin{tabular}{|c|c|c|}
\hline & Haft samfarir & Aldrei haft samfarit \\
\hline \multicolumn{3}{|l|}{ Stelpur } \\
\hline Mjög auðveld & $40,6 \%$ & $54,2 \%$ \\
\hline Auðveld & $30,3 \%$ & $32,1 \%$ \\
\hline Erfið & $18,0 \%$ & $9,6 \%$ \\
\hline Mjög erfið & $8,5 \%$ & $3,3 \%$ \\
\hline Hitti ekki móður & $2,6 \%$ & $0,8 \%$ \\
\hline \multicolumn{3}{|l|}{ Strákar } \\
\hline Mjög auðveld & $50,0 \%$ & $56,0 \%$ \\
\hline Auðveld & $31,0 \%$ & $34,4 \%$ \\
\hline Erfið & $13,2 \%$ & $7,6 \%$ \\
\hline Mjög erfið & $3,9 \%$ & $1,3 \%$ \\
\hline Hitti ekki móður & $2,0 \%$ & $0,7 \%$ \\
\hline \multicolumn{3}{|l|}{ Bari kyn samtals } \\
\hline Mjög auðveld & $45,8 \%$ & $55,1 \%$ \\
\hline Auðveld & $30,5 \%$ & $33,1 \%$ \\
\hline Erfið & $15,1 \%$ & $8,5 \%$ \\
\hline Mjög erfið & $6,0 \%$ & $2,3 \%$ \\
\hline Hitti ekki móður & $2,6 \%$ & $0,8 \%$ \\
\hline
\end{tabular}

Í töflu 2 eru sýnd tengslin milli kynlífsvirkni unglinga og pess hversu auðvelt peir áttu með að tala við feður sína um pað sem ylli peim áhyggjum. Bæði kyn virðast vera í lakari samskiptum við feður sína en mæður og stúlkur meta pau verri en strákar. Mest áhrif á kynlífsvirkni sjást meðal peirra unglinga sem meta samskipti sín við feður mjög erfið par sem peir sem hafa haft samfarir eru um pað bil tvöfalt líklegri til að meta samskiptin með peim hætti en peir sem aldrei hafa stundað kynlíf. Hjá strákunum er lítill munur á pví hvernig peir upplifa samskipti sín með öđrum hætti en mjög erfið og líkunum á pví að peir hafi haft samfarir. Kynlífsvirkni stúlkna virðist hafa meiri tengsl við samskipti peirra við feður en kynlífsvirkni stráka. Stúlkur sem aldrei hafa haft samfarir eru pannig líklegri til pess að meta samskipti sín við feður auðveld eða mjög auðveld. 
Tafla 2. Tengsl kynlífsvirkni unglinga í 10. bekk og samskipta við feður

\begin{tabular}{|c|c|c|}
\hline & Haft samfarir & Aldrei haft samfarir \\
\hline \multicolumn{3}{|l|}{ Stelpur } \\
\hline Mjög auðveld & $22,6 \%$ & $30,6 \%$ \\
\hline Auðveld & $31,7 \%$ & $40,5 \%$ \\
\hline Erfið & $20,8 \%$ & $15,9 \%$ \\
\hline Mjög erfið & $16,4 \%$ & $8,1 \%$ \\
\hline Hitti ekki föður & $8,6 \%$ & $4,9 \%$ \\
\hline \multicolumn{3}{|l|}{ Strákar } \\
\hline Mjög auðveld & $41,4 \%$ & $43,9 \%$ \\
\hline Auðveld & $32,7 \%$ & $38,3 \%$ \\
\hline Erfið & $13,8 \%$ & $11,4 \%$ \\
\hline Mjög erfið & $6,0 \%$ & $3,4 \%$ \\
\hline Hitti ekki föður & $6,0 \%$ & $2,9 \%$ \\
\hline \multicolumn{3}{|l|}{ Bæði kyn samtals } \\
\hline Mjög auðveld & $33,0 \%$ & $37,2 \%$ \\
\hline Auðveld & $31,6 \%$ & $39,5 \%$ \\
\hline Erfið & $16,8 \%$ & $13,5 \%$ \\
\hline Mjög erfið & $10,9 \%$ & $5,8 \%$ \\
\hline Hitti ekki föður & $7,6 \%$ & $3,9 \%$ \\
\hline
\end{tabular}

Áhrif samskipta unglinga við foreldra á kynlífsvirkni voru skoðuð með tvíkosta aðhvarfsgreiningu. Í tilfelli stúlknanna juku góð samskipti við föður marktækt líkurnar á pví að pær hefðu ekki haft samfarir. Prátt fyrir tölfræðilega marktækni $(\mathrm{p}=0,04)$ var gagnlíkindahlutfallið (e. odds ratio) hins vegar frekar lágt (O.R.=1,062) og 95\% öryggismörkin (e. confidence interval) stóðu nærri 1,000 $(95 \%$ C.I.=1,002-1,125). Áhrif samskipta við móður á kynlífsvirkni stúlkna voru á hinn bóginn mun sterkari (O.R. $=1,352 ; 95 \%$ C.I. $=1,202-1,522 ; \mathrm{p}=0,000)$ sem pýðir að pær unglingsstúlkur sem eru í góðum samskiptum við móður sína eru mun ólíklegri til að hafa haft samfarir fyrir 16 ára aldur.

Degar svör strákanna voru skoðuð með tvíkosta aðhvarfsgreiningu kom í ljós að samskipti við mæður höfðu ekki marktæk áhrif á kynlífsvirkni peirra. Hins vegar kom í ljós að pví betri sem samskiptin við föður voru, peim mun ólíklegra var að strákarnir hefðu haft samfarir fyrir 16 ára aldur (O.R. $=1,143 ; 95 \%$ C.I. $=1,035-1,261 ; \mathrm{p}=0,008)$.

\section{Umræða}

Rannsóknin sem hér hefur verið kynnt sýnir fram á tengsl milli kynlífsvirkni unglinga og samskipta peirra við foreldra. Niðurstöður benda til pess að fylgni sé á milli pess hversu auðvelt unglingar eiga með samskipti við foreldra og kynlífsvirkni, p.e.a.s. pað er ólíklegra að unglingar í 10. bekk sem upplifa auðveld samskipti við foreldra séu byrjaðir að stunda kynlíf. Dessar niðurstöður eru í samræmi við fyrri rannsóknir í öðrum löndum. Til dæmis sýndu Lenciauskiene og Zaborskis (2008) fram á að unglingar sem áttu í góðum samskiptum við móður sína voru ólíklegri til að 
hafa byrjað að stunda kynlíf fyrir 16 ára aldur. Í rannsókn Whitaker og Miller (2000) kom fram аð opin samskipti um kynhegðun og notkun smokka hafði mikil áhrif á kynhegðun unglinga. Meðal peirra unglinga sem höfðu ekki rætt við foreldra sína um pessi mál urðu viðhorfin innan félagahópsins ráðandi en í peim tilfellum sem foreldrarnir höfðu tekið pessa umræðu hafði pað mikil áhrif (Whitaker og Miller, 2000). Léleg samskipti við foreldra um pessi mál urðu pví til pess að unglingarnir leituðu frekar til jafnaldra sinna eftir ráðleggingum.

Um fjórðungur íslenskra ungmenna í 10. bekk hefur haft samfarir, samkvæmt pessari rannsókn. Rannsóknir benda til pess að ýmislegt annað en aldur hafi áhrif á upplifun ungmenna af fyrstu kynlífsreynslu, svo sem samskiptahæfni og félagsleg staða. Neikvæð upplifun af fyrstu samförum tengist gjarnan pví að ungmennin voru ekki í rómantísku sambandi eða að annað peirra upplifði prýsting frá hinu (IPPF European Network, 2012). Dví er augljóst að pað að geta leitað til foreldra sinna vakni áhyggjur eða spurningar tengdar kynlífi skiptir miklu máli pegar einstaklingurinn er að stíga sín fyrstu skref á pessu sviði. Niðurstöður okkar renna stoðum undir mikilvægi pess að foreldrar hlúi að börnum og byggi upp góð tengsl til að auðvelda unglingum að leita til sín og stuðli að pví að peir taki upplýstar ákvarðanir í um kynhegðun.

Kynfræðsla felst ekki eingöngu í pví að veita ungmennum upplýsingar heldur einnig að gera peim kleift að ræða um viðhorf til kynlífs og samskipta (Sóley S. Bender, 2012). Dví má ætla að foreldrar hafi mikilvægu hlutverki að gegna í pví að móta hugmyndir unglinga sinna um heilbrigt kynlíf og viðhorf peirra til pess. Rannsóknir á uppeldisháttum foreldra benda til pess að foreldrar sem beiti leiðandi uppeldisháttum fremur en skipandi eða afskiptalitlum styðji betur félags- og tilfinningaproska barna sinna (Baumrind, 1991). Leiðandi uppeldishættir felast í pví að setja unglingum skynsamleg mörk og leggja áherslu á að ræða við pá, sýna peim hlýju og traust (Ragný Póra Guðjohnsen og Sigrún Aðalbjarnardóttir, 2016).

Pá sýna niðurstöður pessarar rannsóknar ótvírætt fram á að á Íslandi hefur kyn unglinga áhrif á bæði samskipti við foreldra og kynhegðun, eins og albjóðleg gögn hafa sýnt (Brooks, 2016; Inchley o.fl., 2016). Tengsl við föður virðast hafa meiri áhrif á kynhegðun drengja en samskipti peirra við móður, en pað bendir til pess að mikilvægt sé að drengir geti rætt um áhyggjuefni sín við feður. Í rannsókn Ársæls Arnarssonar og Hermínu Gunnpórsdóttur (2016) kom fram að íslenskir unglingar af báðum kynjum mátu samskipti sín við feður jákvæðari en börn frá öllum 43 samanburðarlöndunum. Niðurstöður peirra sýndu að flest íslensk börn og ungmenni upplifa pað að feður peirra séu til staðar og auðvelt sé að ná til peirra. Engu að síður kom skýrt fram að íslenskar mæður voru í marktækt betri tengslum við börn sín en feður. Detta kemur einnig fram í peirri rannsókn sem hér er kynnt, enda eru notuð gögn úr HBSC-rannsókninni í báđum tilfellum. Petta er hins vegar einnig í samræmi við niðurstöður annarra (Pleck og Masciadrelli, 2004) sem benda til að feður taki minni pátt í uppeldi unglinga en mæður og að unglingarnir upplifi sterkari tengingu við pær.

Rétt er að ítreka að meirihluti íslenskra unglinga virðist eiga auðvelt með að ræða við foreldra sína um áhyggjur sínar. Dó er ástæða til að skoða enn betur pann hóp sem telur sig eiga erfitt með að ræða áhyggjur sínar við foreldra sína, hvort sem um er að ræða mæður eða feður. Gögnin sem hér hafa verið kynnt sýna að ákveðinn hópur unglinga í 10. bekk sem er byrjaður að stunda kynlíf telur sig eiga erfitt með að ræða við foreldra sína. Á unglingsárunum geta góð samskipti við foreldra haft mikil áhrif á próun félagslegra gilda, veitt ungmennunum styrk til að fást við krefjandi aðstæður og hjálpað peim að sneiða hjá ýmsum neikvæðum páttum sem tengjast áhættuhegðun, eins og reykingum, vímuefnanotkun og ofbeldi. Opin samskipti innan fjölskyldna tengjast einnig minni líkum á áhættusamri kynhegðun á unglingsaldri. Í peim tilfellum par sem pessi samskipti eru lakari koma hins vegar oft fram alvarlegar afleiðingar tengdar heilsu og vellíðan (Brooks, 2016; Duncan o.fl., 2007; Whitaker og Miller, 2000).

Annmarkar rannsóknarinnar sem hér var kynnt eru meðal annars peir að mæling á samskiptum við foreldra var mjög einföld, par sem eingöngu er miðað við svar við einni spurningu. Samskipti við foreldra felast einnig í margvíslegu daglegu samneyti og jafnvel bví einu að foreldrar og unglingar séu heima á sama tíma (Bulanda og Majumdar, 2009). Dví ber að taka niðurstöðum 
með fyrirvara um pað hve margpætt samskiptaformin eru; hér hefur eingöngu verið miðað við mat unglinganna sjálfra á pví hve auðvelt eða erfitt peim pyki að ræða við móður sína eða föður um áhyggjur sínar. Pá var kynlífsvirkni mæld með tvíkosta spurningu til unglinganna sjálfra um pað hvort peir hefðu stundað samfarir, par sem boðið var upp á að svara neikvæett eða jákvætt. Engin tilraun var gerð til að gera greinarmun á peim ungmennum sem gæu hafa stundað samfarir margoft eða peirra sem hefðu sofið hjá aðeins einu sinni. Ungmenni eru hópur ólíkra einstaklinga með fjölbreyttan félagslegan bakgrunn sem mótar viðhorf peirra og reynslu. Ljóst er að fjölbreyttari rannsóknaraðferðir, svo sem viðtöl við ungmenni, myndu dýpka mjög pær rannsóknarniðurstöður sem hér voru kynntar.

Engu að síður er rannsókn pessi pýðingarmikið framlag til að varpa ljósi á kynlífsvirkni íslenskra ungmenna og möguleg tengsl við foreldra. Niðurstöður staðfesta að kyn foreldra og kyn ungmenna mótar reynslu peirra. Frekari rannsókna er pörf til að skoða reynslu ólíkra pjóðfélagshópa, svo sem LBGTQ-ungmenna og fatlaðra ungmenna, og til að varpa ljósi á reynslu feðra og mæðra af pví að skapa og viðhalda traustum og opnum samskiptaleiðum við ungmenni sín.

\section{Sexual activity of teenagers and communication with parents}

Teenagers face many psychological and social challenges, amongst them to develop as sexually responsible individuals. Early adulthood is characterized by increased independence and the peer group often shapes the values and activities of individuals. However, parents still have an important role as they help their teenagers to navigate the sometimes stormy waters of early adulthood. The purpose of the present study is to explore the connections between the sexual activities of teenagers and their selfreported quality of relationships with parents. Also to explore whether gender is a significant factor in teenagers' responses. We used the Icelandic data set from the 2014 Health Behaviour in School-aged Children (HBSC) study. The sample consisted of 3618 grade 10 Icelandic adolescents; 1731 girls and 1783 boys. The participants were asked whether they had experienced sexual intercourse; and they were also asked to evaluate how easy or difficult they find talking to their parents about their concerns.

Research has shown that early sexual activity can influence the self-image of teenagers, as well as their wellbeing, social status and future sexual experiences. It has been established that parental support makes a difference and correlates positively with the wellbeing of teenagers. Parents should try to maintain open channels of communication so that teenagers can talk to them about their concerns, such as sex. Early onset sexual activity has been related to other kinds of risky behavior, such as drug abuse and violence. Nevertheless, it is important to recognize that experiencing sex is a normal and important part of early adulthood and sex should, therefore, not be a taboo topic of discussion within families. A recent Icelandic study showed that Icelandic teenagers evaluate communication with their parents as being better than do teenagers from 43 other countries. The majority of participants found it easy or very easy to communicate with parents: $76.3 \%$ found it easy or very easy to communicate with their mothers and $64.6 \%$ with their fathers. A quarter of 10 th graders, $24.4 \%$ of boys and $23.0 \%$ of girls, had had intercourse. The main result of the study is that teenagers who find it difficult to communicate with their parents are more likely to have had sex. Both girls and boys report worse communication with their fathers than their mothers. Girls rate their communication with parents less favorably than boys. This is line with previous research that indicates that more teenagers connect more easily with mothers than fathers. This study showed that there is a group of teenagers who are sexually active and report that they do not easily communicate with their parents.

Key words: Teenagers, sexual activity, communication, parents, gender difference 


\section{Um höfundana}

Kolbrún P. Pálsdóttir (kolbrunp@hi.is) er dósent og forseti Menntavísindasviðs Háskóla Íslands. Hún lauk bakkalárprófi í heimspeki árið 1997, meistaranámi í uppeldis- og menntunarfræði árið 2001 og doktorsprófi í menntunarfræðum árið 2012, öllu frá Háskóla Íslands. Rannsóknarsvið Kolbrúnar eru einkum tengsl formlegs og óformlegs náms, uppeldi og menntun, og samvinna í skóla- og frístundastarfi.

Ársæll Arnarsson (arsaell@hi.is) er prófessor í tómstunda- og félagsmálafræði við Menntavísindasvið Háskóla Íslands. Hann lauk BA-prófi í sálfræði 1993, MS-gráđu í heilbrigðisvísindum 1997 og PhD-gráđu í líf- og læknavísindum frá H.Í. árið 2009. Síðastliðinn áratug hafa rannsóknir hans aðallega beinst að heilsufari og líðan unglinga.

\section{About the authors}

Kolbrún P. Pálsdóttir (kolbrunp@hi.is) is associate professor and Dean, School of Education, University of Iceland. She earned a BA degree in philosophy in 1997 and a master's degree in education in 2001, both from the University of Iceland. Kolbrún defended her Ph.D. thesis in education at the University of Iceland in 2012. Her research interests include the relationship between formal and informal learning, leisure-time pedagogy and education, and collaboration in education.

Ársæll Arnarsson (arsaell@hi.is) is a professor of leisure studies in the University of Iceland School of Education. He completed a BA degree in psychology in 1993, an MSc degree in Health Sciences in 1997 and a PhD in Biomedical Sciences in 2009 from the University of Iceland. For the past decade his research has focused on the health and well-being of adolescents.

\section{Heimildir}

Adams, K. S., Sheldon-Keller, A. E. og West, M. (1996). Attachment organization and history of suicidal behavior in clinical adolescents. Journal of Consulting and Clinical Psychology, 64(2), 264-272.

Arnarsson, A., Portebny, T., Torsheim, T. og Eriksson, C. (i prentun). Trends in Nordic adolescents' communication with their parents. Nordic Welfare Research.

Avery, L. og Lazdane, G. (2008). What do we know about sexual and reproductive health of adolescents in Europe? European Journal of Contraceptive and Reproductive Health Care, 13(1), 58-70.

Ársæll Arnarsson og Hermína Gunnpórsdóttir. (2016). Íslenskir feður-bestir í heimi? Í Helga Ólafsdóttir og Thamar M. Hejstra (ritstjórar), Djóðarspegill - Rannsóknir í félags- og mannvísindum XVII (bls. 1-8). Reykjavík: Félagsvísindastofnun Háskóla Íslands.

Ársæll Arnarsson, Kristín Heba Gísladóttir og Stefán Hrafn Jónsson. (2016). Algengi kynferðislegs áreitis og ofbeldis gegn íslenskum unglingum. Laknablaðið, 102(6), 293-299. doi: 10.17992/lbl.2016.06.87

Baumrind, D. (1991). Effective parenting during the early adolescent transition. Í P. A. Cowan og M. Hetherington (ritstjórar), Family transitions (bls. 111-163). Hillsdale, NJ: Erlbaum.

Bohlin, G., Hagekull, B. og Rydell, A. (2000). Attachment and social functioning: A longitudinal study from infancy to middle childhood. Social Development, 9(1), 24-39.

Bowlby,J. (1977). The making and breaking of affectional bonds. British Journal of Psychiatry, 130(3), 201-210.

Brooks, F. (2016). Social context. Í J. Inchley, D. Currie, T. Young, O. Samdal, T. Torsheim, L. Augustson, F. Mathison, A. Aleman-Diaz, M. Molcho, M. Weber og V. Barnekow (ritstjórar), Growing up unequal: Gender and socioeconomic differences in young people's health and well-being (bls. 21-68). Kaupmannahöfn: WHO Regional Office for Europe.

Bulanda, R. E. og Majumdar, D. (2009). Perceived parent-child relations and adolescent self-esteem. Journal of Child \& Family Studies, 18(2), 203-212. doi.org/10.1007/s10826-008-9220-3

Carlson, M. J., Sampson, M. C., og Sroufe, L. A. (2003). Implications of attachment theory and research for developmental-behavioral paediatrics. Journal of Developmental and Behavioral Pediatrics, 24(5), 364-379.

Commendador, K.A. (2010). Parental influences on adolescent decision making and contraceptive use. Pediatric Nursing, 36(3), 147-170. PMID: 20687307 
Duncan, P., Garcia,A., Frankowski, B., Carey, P., Kallock, E., Dixon, R. og Shaw, J. S. (2007). Inspiring healthy adolescent choices: A rationale for and guide to strength promotion in primary care. Journal of Adolescent Health, 41(6), 525-535.

Eaton, D. K., Kann, L., Kinchen, S., Ross, J., Hawkins, J., Harris, W. A., . . Centers for Disease Control and Prevention. (2006).Youth risk behavior surveillance-United States. (2005). Journal of School Health, 76(7), 353-372.

Fergus, S., Zimmerman, M. A. og Caldwell, C. A. (2007). Growth trajectories of sexual risk behavior in adolescence and young adulthood. American Journal of Public Health, 97(6), 1096-1101.

Finzi, R., Ram.A., Har-Even, D. Shnit, D. og Weizman, A. (2001). Attachment styles and aggression in physically abused and neglected children. Journal of Youth and Adolescence, 30(6), 769-786.

Flouri, E., og Buchanan, A. (2003). The role of father involvement in children's later mental health. Journal of Adolescence, 26(1), 63-78.

Graham, C.A. og Easterbrooks, M.A. (2000). School-aged children's vulnerability to depressive symptomatology: The role of attachment security, maternal depressive symptomatology, and economic risk. Development and Psychopathology, 12(2), 201-213.

Hansen, B. T., Kjær, S. K., Munk, C., Tryggvadóttir, L., Sparén P., Hagerup-Jenssen, M., Liaw, K. L., Nygård, M. (2010). Early smoking initiation, sexual behavior and reproductive health - a large population-based study of Nordic women. Preventive Medicine, 51(1), 68 - 72.

Heilborn, M. L. og Cabral, C. S. (2010). Teenage pregnancy. From sex to social pathology. Í P. Aggleton og R. Parker (ritstjórar), Routledge handbook of sexuality, health and rights, bls. 164-172. New York: Routledge.

Inchley, J., Currie, D., Young, T., Samdal, O., Torsheim, T., Augustson, L., . . Barnekow,V. (2016). Growing up unequal: gender and socioeconomic differences in young people's health and well-being. Health Behaviour in School-aged Children (HBSC) study: International report from the 2013/2014 survey. Kaupmannahöfn: WHO Regional Office for Europe.

IPPF European Network. (2012). Increasing the knowledge base on young people's sexual and reproductive health and rights in Europe. Summary report of qualitative research conducted in five European countries under the SAFE II project. Brussel: IPPF European Network.

Jacobsen, T. og Hofmann,V. (1997). Children's attachment representations: Longitudinal relations to school behavior and academic competency in middle childhood and adolescence. Developmental Psychology, 33(4), 703-710.

Lenciauskiene, I. og Zaborskis, A. (2008). The effects of family structure, parent-child relationship and parental monitoring on early sexual behaviour among adolescents in nine European countries. Scandinavian Journal of Public Health, 36(6), 607-618.

Marcus, R. F. og Sanders-Reio, J. (2001). The influence of attachment on school completion. School Psychology Quarterly, 16(4), 427-444.

Parker,J. og Benson, M. (2004). Parent-adolescent relations and adolescent functioning: Self-esteem, substance abuse, and delinquency. Adolescence, 39(155), 519-530.

Pleck, J. H. og Masciadrelli, B. P. (2004). Paternal involvement by U. S. residential fathers: Levels, sources, and consequences. Í M. E. Lamb (ritstjóri), The role of the father in child development (bls. 222-271). Hoboken, NJ:Wiley.

Poulin, C. og Graham, L. (2001). The association between substance use, unplanned sexual intercourse and other sexual behaviours among adolescent students. Addiction, 96(4), 607-621.

Ragný Póra Guðjohnsen og Sigrún Aðalbjarnardóttir. (2016). Uppeldisaðferðir foreldra og viðhorf ungmenna til virkrar borgaralegrar pátttöku fólks. Í Guðrún Kristjánsdóttir, Sigrún Aðalbjarnardóttir og Sóley S. Bender (ritstjórar), Ungt fólk. Tekist á við tilveruna (bls. 265-286). Reykjavík: Hið íslenska bókmenntafélag.

Sóley S. Bender. (2012). Ferlismat á nýju kynfræðsluefni fyrir unglinga.Tímarit hjúkrunarfræðinga, 88(4), 48-56.

Sóley S. Bender. (2016). Kynhegðun unglinga. Snemma byrjað að stunda kynlíf. Í Guðrún Kristjánsdóttir, Sigrún Aðalbjarnardóttir og Sóley S. Bender (ritstjórar), Ungt fólk. Tekist á við tilveruna (bls. 315-334). Reykjavík: Hið íslenska bókmenntafélag. 
Vašičcková, J., Hodačová, L., Půžová, Z. og Tabaka, I. (2017). Trends in parent-adolescent communication in the Czech Republic between 2002 and 2014: Results of the HBSC study. Central European Journal of Public Health, 25(1), 36-41. doi: 10.21101/cejph.a4952.

Velferðarráðuneytið og Hagstofa Íslands. (2015). Félagsvísar 2015 (4. útgáfa). Reykjavík: Höfundur.

Warren, S. L., Houston, L., Egeland, B. og Sroufe, L. A. (1997). Child and adolescent anxiety disorders and early attachment. Journal of the American Academy of Child and Adolescent Psychiatry, 36(5), 637-644.

Wetherill, R. R., Neal, D. J. og Fromme, K. (2010). Parents, peers, and sexual values influence sexual behavior during the transition to college. Archives of Sexual Behavior, 39(3), 682-694.

Whitaker, D. J. og Miller, K. S. (2000). Parent-adolescent discussions about sex and condoms: Impact on peer influences of sexual risk behavior. Journal of Adolescent Research, 15(2), 251-273.

World Health Organization. (2016). Action plan for sexual and reproductive health. Towards achieving the 2030 agenda for sustainable development in Europe - leaving no one behind. Sótt af http://www.euro. who.int/_data/assets/pdf_file/0003/322275/Action-plan-sexual-reproductive-health.pdf?ua=1

Young, H. (2013). Sexual health questions for use in the HBSC Study 2013/2014: Findings from an international pilot study [fyrirlestur á HBSC Spring Meeting; 19. júní 2013; St Andrews, Skotlandi].

Kolbrún P. Pálsdóttir og Ársæll Arnarsson. (2018).

Kynlífsvirkni unglinga og samskipti peirra við foreldra.

Netla - veftímarit um uppeldi og menntun. Sérrit 2018 - Menntakvika 2018. Menntavísindasvið Háskóla Íslands.

Sótt af http://netla.hi.is/serrit/2018/menntakvika_2018/02.pdf

DOI: https://doi.org/10.24270/serritnetla.2019.26 